The Israeli Journal of Aquaculture - Bamidgeh, IJA.72.2020.1305530, 14 pages

CCBY-NC-ND-4.0 • https://doi.org/10.46989/001c.21456

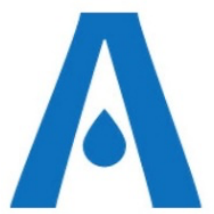

The $I J A$ is a peer-reviewed open-access, electronic journal, freely available without charge to users

Produced by the AquacultureHub non-profit Foundation Sale of $I J A$ papers is strictly forbidden

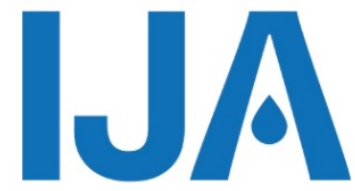

\title{
Antibacterial Activity of Essential Oils and Extracts of Some Medicinal Plants against Bacterial Fish Pathogens
}

\author{
Seçil Metin ${ }^{1}$, Nimet Kara ${ }^{2}$, Behire Isıl Didinen ${ }^{1 *}$, Ayşegül Kubilay $^{1}$ \\ ${ }^{1}$ Isparta University of Applied Sciences, Egirdir Fisheries Faculty, 32260, Isparta-Turkey \\ ${ }^{2}$ Isparta University of Applied Sciences, Department of Field Crops, Faculty of \\ Agriculture, Isparta, Turkey
}

Keywords: antibacterial activity, essential oil, extracts, agar diffusion, bacterial fish pathogens

\begin{abstract}
In this study, chemical compositions and in vitro antibacterial activities the components of essential oils and extracts of sage (Salvia officinalis L.), rosemary oil (Rosmarinus officinalis L.), lavandin (Lavandula $x$ intermedia var. Super), and hyssop (Hyssopus officinalis L.) against fish pathogens: Gram-negative bacteria (Aeromonas caviae, Aeromonas hydrophila, Vibrio anguillarum, Yersinia ruckeri, Edwardsiella tarda, Pseudomonas aeruginosa) and Gram-positive bacteria (Lactococcus garvieae, Staphylococcus warneri, Vagacoccus salmoninarum) were investigated with Well Diffusion Agar assay. The composition of the essential oils and extracts were analyzed with GC/MS and HPLC, respectively. A total of 42 components in sage, 39 in rosemary, 44 in lavender, and 46 in hyssop were detected. As a result of this study, the sage and rosemary oils exhibited a broad-spectrum inhibitory effect (a strong antibacterial effect against Gram (+) and Gram (-) pathogens). Lavandin oil also showed a strong antibacterial effect against a majority of pathogens. The spectrum of inhibitory activity of hyssop oil was found narrower than other plant oils. In further studies, in vivo antibacterial effects of sage, rosemary and lavandin essential oils should be investigated.
\end{abstract}

\footnotetext{
* Corresponding author: Tel.: +90 2462146436, e-mail: behiredidinen@hotmail.com
} 


\section{Introduction}

The aim of this study is to characterize the phenotype, taxonomic position and antibiotic susceptibility of $P$. shigelloides pathogen isolated from enteritis-infected channel catfish. As far as we know, this is the first report of enteritis caused by $P$. shigelloides in channel catfish. In aquaculture, antimicrobial agents are widely used to prevent fish diseases caused by infectious agents (Schnick et al., 1997). It is known that the unconscious use of antimicrobial agents in the treatment of fish diseases causes many negative effects on the environment, fish, and human health (Schnick et al., 1997; Dos Santos, 2000). Therefore, herbal products' use to control fish pathogens in aquaculture is an alternative and current practice (Abutbul et al., 2005; Bansemir et al., 2006; Ekici et al., 2011; Haniffa and Kavitha, 2012; Al Laham and Al Fadel, 2014; Turker and Yıldırım, 2015; Ontas et al., 2016; Diler et al., 2017 a,b; Metin et al.,2017).

Sage, rosemary, lavender and hyssop are plants important medicinal and aromatic plants belonging to the Lamiaceae family. Due to the plants' essential oil, the odor and taste are antibacterial and antioxidant and are used in many industrial fields such as food, cosmetics, perfumery, and pharmaceutical industries.

Sage (Salvia L.) is perennial, grows up $50-100 \mathrm{~cm}$ in length, and has a semi-bushy structure (Baydar, 2013). Sage has economically evaluated leaves and the essential oil content of leaves varies between $1-2.5 \%$. Sage has a very high antimicrobial and antioxidant effects and it is stated that these effects are mostly caused by components such as 1,8-cineol, a-tuyon, $\beta$-tuyon and camphor (Baricevic and Bartol 2000).

Hyssop (Hyssopus officinalis L.) is a perennial, grows up to $50 \mathrm{~cm}$ and has blueviolet flowering. Used parts of hyssop are leaves and flowers. Hyssop contains $0.1-1.8 \%$ of essential oil with maximum content at the flowering (Jankovsky and Landa, 2002). Pinocamphone, $\beta$-pinene'i, isopinocamphone were the essential oil components (Garg et al.,1999). Camphene and pinene are spasmolytics, and pinene has bactericidal effects.

Lavender (Lavandula sp.) is a perennial plant in semi-bushy form. Lavender has flowers of varying colors ranging from blue to viola, $50-100 \mathrm{~cm}$ in length. The ratio of essential oil in fresh lavender flowers varies between 1-3\%. Commercial lavender essential oils contain more than 100 terpenoid compounds and the most important essential oil components are linalyl acetate, linalool, cineol and camphor (Kara, 2011). Rosemary (Rosmarinus officinalis L.) is a perennial plant, $50-100 \mathrm{~cm}$ height, shrub appearance; evergreen leaves in the winter, the flowers are pale blue colored (Baytop, 1984). There are secretory hairs that carry plenty of essential oil under the surface of the leaves. Rosemary leaves contain $1.0-2.0 \%$ of essential oil. The main of components of essential oil were borneol, 1,8 cineole (eucalyptol) and camphor (Baskaya et al.,2016). In rosemary, carnosic acid, carnosol, rosmarinic acid and rosmanol have antioxidant properties; borneol, 1,8-cineole, camphor and bornyl acetate are compounds used in food preservation (Sasikumar, 2004).

In this study was investigated the in vitro antibacterial effects against the fish pathogens of medicinal plants, sage (Salvia officinalis L.), rosemary oil (Rosmarinus officinalis L.), lavandin (Lavandula $x$ intermedia var. Super) and hyssop (Hyssopus officinalis L.) essential oils and extracts. In addition, their components were determined.

\section{Plant materials}

\section{Materials and Methods}

In this study, sage (Salvia officinalis L.), rosemary oil (Rosmarinus officinalis L.), lavandin (Lavandula $x$ intermedia var. Super) and hyssop (Hyssopus officinalis L.) were used as plant materials. The samples during the blooming stage were taken from the experimental farm of the Agriculture Faculty, Isparta Applied Sciences University. The plants were dried in the shadow and the stem parts are separated after drying. The leaves of sage and rosemary plants, the bud of lavandin plants and leaf and flower parts of hyssop were used to obtaining plant essential oils and extracts. 
using Clevenger apparatus according to the standard procedure described in European Pharmacopoeia for determining the oil content ( $\mathrm{v} / \mathrm{w} \%)$. The concentrations of 1000,500 , 250,125 and $62.5 \mu \mathrm{L} \mathrm{mL}^{-1}$ of the essential oils in methanol were prepared (Borisutpeth et al., 2005).

\section{Preparation of extracts}

Plant extracts were prepared from a representative sample of $100 \mathrm{~g}$ of each powdered plant material and were taken into a $1 \mathrm{~L}$ capacity Erlenmeyer flask. $1 \mathrm{~L}$ of $\mathrm{n}$ hexzane was added to it and shaken for $24 \mathrm{~h}$ in a horizontal shaker at $120 \mathrm{rpm}$ at room temperature. Then, the $\mathrm{n}$-hexane in the suspansion was removed by rotary evaporator and plant extracts were prepared. The extracts diluted at \% 20 concentrations with acetone water (\%10). The extract solutions were kept in a refrigerator at $4{ }^{\circ} \mathrm{C}$ until were used (Gokce et al., 2007).

Gas chromatography-mass spectroscopy analysis of the essential oil

CP-Wax $52 \mathrm{CB}(50 \mathrm{~m} \times 0.32 \mathrm{~mm}$; film thickness $=0.25 \mu \mathrm{m})$ was used as the column for determining the essential oil components of the plants. Oven temperature program: after at $40^{\circ} \mathrm{C}$ waiting for 2 minutes, reaches $4^{\circ} \mathrm{C}$ degrees per minute at $250{ }^{\circ} \mathrm{C}$. Waiting at $250^{\circ} \mathrm{C}$ for 5 minutes. Injection block temperature $250^{\circ} \mathrm{C}$, Detector temperature $250^{\circ} \mathrm{C}$, Detector energy flow $70 \mathrm{eV}$, Ionization type: EI, Gas used: Helium ( $20 \mathrm{~mL} \mathrm{~min}{ }^{-1}$ ), Flow rate $1,61 \mathrm{psi}$, sample preparation $7.5 \mu \mathrm{L}$ of essential oil $+1500 \mu \mathrm{L}$ dichloromethane. Each component was identified by comparison from the Wiley, Nist, Tutor, FFNSC library of mass Spectra. The component amount was determined by proportioning the relative blocks of the peak areas to the total peak area.

\section{HPLC analysis of the extracts}

Agilent Eclipse XDB-C18 (250x4, $60 \mathrm{~mm})$ 5-micron column was used for the determination of phenolic compounds in plant extracts. The temperature is $30{ }^{\circ} \mathrm{C}$, the mobile phase has a flow rate of $0.8 \mathrm{~mL} \mathrm{~min}^{-1}$ and the injection volume is $20 \mu \mathrm{L}$. A solution ( $3 \%$ acetic acid) and $B$ solution (Methanol) were used as mobile phase.

\section{Bacterial fish pathogens}

Pathogen strains were obtained from the culture collection in the Fish Diseases Laboratory of the Egirdir Fisheries Faculty. The bacterial fish pathogens and their origins used in the study were given in Table $\mathbf{1}$.

\begin{tabular}{lll}
\hline \multicolumn{2}{l}{ Table 1} & Bacterial fish pathogens and their origins \\
\hline No & Bacteria & Origin \\
\hline 1 & Aeromonas sobria & Rainbow trout-Mugla-Turkey \\
\hline 2 & Aeromonas caviae & ATCC 15468 \\
\hline 3 & Aeromonas hydrophila & ATCC 7966 \\
\hline 4 & Vibrio anguillarum & Rainbow trout-Mugla-Turkey \\
\hline 5 & Pseudomonas aeroginosa & ATCC 27953 \\
\hline 7 & Yersinia ruckeri & Rainbow trout-Mugla-Turkey \\
\hline 8 & Edwardsiella tarda & DSMZ 300052 \\
\hline 9 & Lactococcus garvieae & Rainbow trout -Mugla-Turkey \\
\hline 11 & Staphylococcus warneri & Rainbow trout -Mugla-Turkey \\
\hline
\end{tabular}


Antibacterial effects of essential oils and extracts were determined by well diffusion agar assay. For in vitro antibacterial activity was used tryptic soy agar (TSA) for all pathogen. Salt (2\%) was added to TSA and tryptic soy broth (TSB) for $V$. anguillarum. The pathogen culture was grown in $4 \mathrm{~mL}$ TSB for $1 \mathrm{~d}$ at $25^{\circ} \mathrm{C}$, and $100 \mu \mathrm{L}$ of each culture was mixed into $100 \mathrm{~mL}$ of melted TSA. After solidifying and drying for 15-20 minutes, wells were punched (diameter $=3 \mathrm{~mm}$ ) and $30 \mu \mathrm{L}$ from extract solutions or the essential oils of each plant added to the wells in triplicate. Methanol for essential oils and acetone for extracts was used as control. After incubation at $25^{\circ} \mathrm{C}$ for 24 hours, the diameters of the inhibition zones were measured. Inhibition activity was considered to strong for $>15 \mathrm{~mm}$, medium for 8-15 mm and weak for 1-8 $\mathrm{mm}$ zone diameters (Bansemir et al., 2006).

\section{Statistical analysis}

Data (zone diameters) were assessed by one way analysis of variance ANOVA SPSS 17.0 package program (SPSS Inc., Chicago, IL, USA). Duncan's multiple range test were used to determine the significant variation $(p<0.05)$ and the significance level was chosen as $\mathrm{P}=0.05$.

\section{Identification of the pathogen}

\section{Results}

\section{GC / MS analysis}

The components of sage, hyssop, rosemary and lavandin essential oils by GC-MS were given in Table 2. A total of 42 components in sage, 39 in rosemary, 44 in lavandin and 46 in hyssop were detected. 1,8-cineole (eucalyptol) (27.08\%), thujone (20.52\%), camphor $(16.99 \%)$, beta pinene $(4.07 \%)$ in sage; camphor $(29.17 \%), 1,8$-cineole $(26.36 \%)$, borneol $(7.34 \%)$, alpha pinene $(6.72 \%)$ camphene $(4.95 \%)$ in rosemary; linalool $(42.21 \%)$, linalyl acetate $(23.61 \%)$, borneol $(5.38 \%)$, terpineol $(5.07 \%)$ in lavandin and beta-phellandrene $(49.79 \%)$, beta- myrcene $(10.16 \%)$, linalool $(10.04 \%)$ ve elemol- alpha $(3,62 \%)$ in hyssop were determined (Table 2 ). 
Table 2 Essential oil components of sage, hyssop, rosemary and lavandin (\%)

\begin{tabular}{|c|c|c|c|c|c|}
\hline Component & $\begin{array}{c}\text { Retention } \\
\text { Time }\end{array}$ & Sage & Rosemary & Lavandin & Hyssop \\
\hline Tricyclene & 6.36 & 0.12 & 0.16 & - & - \\
\hline Alpha-Thujene & 6.44 & 0.13 & - & - & - \\
\hline Alpha- Pinene & 6.70 & 3.06 & 6.72 & 0.18 & 0.18 \\
\hline Camphene & 7.28 & 3.67 & 4.95 & 0.28 & - \\
\hline Verbenene & 7.39 & - & 0.31 & - & - \\
\hline Sabinene & 8.13 & 0.07 & - & - & 0.88 \\
\hline Beta- pinene & 8.33 & 4.02 & 1.36 & 0.15 & 0.91 \\
\hline 3- Octanone & 8.57 & 0.08 & 0.08 & 0.57 & - \\
\hline Beta-Myrcene & 8.78 & 1.61 & 0.94 & 1.36 & 10.16 \\
\hline Pseudolimonene & 9.42 & - & - & - & 0.37 \\
\hline Phellandrene-alpha & 9.50 & - & 0.19 & - & - \\
\hline 1-Phellandrene & 9.53 & - & - & - & 0.16 \\
\hline Delta 3-carene & 9.62 & - & 0.77 & - & - \\
\hline Hexyl acetate & 9.75 & - & - & 0.69 & - \\
\hline Terpinene- alpha & 10.01 & 0.20 & 0.43 & - & - \\
\hline Cymole & 10.35 & - & 1.79 & - & - \\
\hline Para-cynmene & 10.36 & 0.64 & - & 0.07 & - \\
\hline Beta-Phellandrene & 10.81 & - & - & - & 49.79 \\
\hline Limonene & 10.60 & 0.88 & 2.03 & 0.87 & - \\
\hline 1.8-cineole (eucalyptol) & 10.74 & 27.08 & 26.36 & 3.31 & - \\
\hline Cis-ocimene & 10.94 & 0.23 & 0.04 & 0.91 & 0.19 \\
\hline Beta-ocimene & 11.45 & 0.10 & 0.04 & 1.50 & 0.94 \\
\hline Gamma-terpinene & 12.02 & 0.33 & 0.67 & - & - \\
\hline Trans-sabinene hydrate & 12.67 & 0.14 & - & - & - \\
\hline Linalool oxide (trans) & 12.71 & - & - & 0.21 & - \\
\hline Alpha-terpinolene & 13.47 & 0.12 & 0.46 & 0.20 & - \\
\hline Linalool oxide (cis) & 13.61 & - & - & 0.11 & - \\
\hline Linalool & 14.67 & 3.84 & 2.70 & 42.21 & 10.04 \\
\hline Hexyl propionate & 14.74 & - & - & 0.24 & - \\
\hline Thujone & 14.77 & 20.52 & 0.12 & - & 0.30 \\
\hline 1-octen-3-yl acetate & 14.87 & - & - & 0.24 & - \\
\hline p-menth-2- en-1-ol & 15.69 & - & - & - & 0.31 \\
\hline Trans sabinene hydrate & 15.72 & 0.09 & 0.06 & - & 0.16 \\
\hline Alloocimen & 15.98 & 0.05 & - & 0.11 & - \\
\hline Cis- Sabinol & 16.85 & 0.29 & - & - & - \\
\hline Camphor & 17.02 & 16.99 & 29.17 & 2.79 & 0.57 \\
\hline 3 oktyne. 2.2- dimenthyl & 17.15 & - & - & - & 0.10 \\
\hline Hexyl isobutyrate & 17.19 & - & - & 0.17 & - \\
\hline 3- pinanone & 17.80 & 0.28 & - & - & - \\
\hline Lavandulol & 18.23 & 0.08 & - & 0.18 & 0.11 \\
\hline Borneol & 18.65 & 2.67 & 7.34 & 5.38 & 0.72 \\
\hline Pinocamphone & 18.76 & 0.12 & 0.74 & - & - \\
\hline 4-Terpineol & 19.13 & 0.62 & 0.94 & 0.17 & 0.18 \\
\hline Cyrptone & 19.42 & - & - & 0.33 & 0.57 \\
\hline Para-cymen-8- ol & 19.53 & 0.05 & 0.13 & 0.06 & - \\
\hline Terpineol-alpha & 20.14 & 1.02 & 2.94 & 5.07 & 1.29 \\
\hline $\mathrm{p}$ - allylanisole & 20.22 & - & - & - & 0.12 \\
\hline Berbenone & 20.79 & - & 1.86 & - & - \\
\hline
\end{tabular}




\begin{tabular}{|c|c|c|c|c|c|}
\hline Nerol & 22.07 & - & - & 0.74 & - \\
\hline Hexyl 2- methyl butyrate & 22.82 & - & - & 0.11 & - \\
\hline$z$-sitral & 22.83 & - & - & - & 0.12 \\
\hline Cumaldehyde & 22.97 & - & - & 0.10 & 0.15 \\
\hline $\begin{array}{l}\text { Butanoate- hexyl-3 } \\
\text { methyl }\end{array}$ & 23.24 & - & - & 0.10 & - \\
\hline Carveol & 23.31 & - & 0.10 & - & - \\
\hline Linalyl Acetate & 23.72 & 1.13 & 0.70 & 23.61 & 2.46 \\
\hline e-citral & 24.79 & - & - & - & 0.14 \\
\hline Citral & 24.83 & - & - & 0.09 & - \\
\hline Phellandral & 25.25 & - & - & - & 0.17 \\
\hline Bornil acetate & 25.84 & 0.75 & 2.83 & 0.07 & 0.10 \\
\hline Lavandulyl acetate & 25.96 & 0.12 & - & 2.36 & 0.31 \\
\hline Sabinol & 26.16 & 0.09 & - & - & - \\
\hline Bicycloelemene & 28.92 & - & - & - & 1.17 \\
\hline Tiglate- hexyl & 28.93 & - & - & 0.20 & - \\
\hline Piperitenone & 29.19 & - & 0.09 & - & - \\
\hline Neryl acetate & 30.82 & 0.10 & 0.05 & 0.98 & 0.29 \\
\hline Copaene- alpha & 31.69 & - & 0.10 & - & - \\
\hline Geranyl Acetate & 32.12 & 0.17 & 0.08 & 1.91 & - \\
\hline Bourbonene- beta & 32.17 & - & - & - & 1.09 \\
\hline Methyleugenol & 33.43 & - & - & - & 0.15 \\
\hline Gurjunene- alpha & 33.69 & - & - & - & 0.46 \\
\hline Caryophyllene & 34.42 & 3.32 & 1.49 & 0.57 & 1.26 \\
\hline Beta- cubenene & 35.09 & - & - & - & 0.21 \\
\hline Alpha- humulene & 36.68 & 0.79 & 0.17 & - & 0.22 \\
\hline Farnesene- e- beta & 36.86 & - & - & 0.32 & - \\
\hline Alloaromadendrene & 36.97 & - & - & - & 2.07 \\
\hline Germacrene-d & 38.33 & - & - & 0.15 & 2.79 \\
\hline $\begin{array}{l}\text { Dehydroaromadendraneh } \\
\text { ene }\end{array}$ & 38.75 & - & - & - & 0.16 \\
\hline Bicyclogermacrene & 39.24 & - & - & - & 2.08 \\
\hline Geranyl Isovalerate & 40.02 & - & - & 0.18 & - \\
\hline Cadinene- gamma & 40.35 & - & 0.08 & - & 0.27 \\
\hline Delta cadinene & 40.74 & - & 0.20 & - & - \\
\hline Elemol-Alpha & 42.58 & - & - & - & 3.62 \\
\hline Spathulenol & 44.12 & - & - & - & 0.62 \\
\hline Caryophyllene oxide & 44.37 & 0.74 & 0.13 & 0.13 & - \\
\hline Ledene & 45.19 & 3.29 & - & - & - \\
\hline Humulene oxide & 46.02 & 0.29 & - & - & - \\
\hline Eudesmol- epi-gamma & 47.43 & - & - & - & 0.68 \\
\hline Muurolol-alpha- epi & 48.02 & - & - & 0.08 & 0.32 \\
\hline Guaiol & 48.72 & - & - & - & 1.02 \\
\hline Alpha-bisabolol & 50.64 & - & - & 0.78 & - \\
\hline
\end{tabular}

HPLC analysis

Caffeic acid, p-coum acid, ferulic acid, hesperidine, cinnamic acid and rosmarinic acid were determined as phenolic compounds in the plant extracts (Table $\mathbf{3}$ ). 
Table 3 Phenolic compounds of sage, hyssop, rosemary and lavandin extracts $\left(\mu \mathrm{g} \mathrm{mL}^{-1}\right)$

\begin{tabular}{lcccc}
\hline Compounts & Sage & Rosemary & Lavandin & Hyssop \\
\hline Caffeic acid & - & - & - & 0.5 \\
\hline P - coum acid & - & 1.6 & 2.0 & 0.2 \\
\hline Ferulic acid & - & 0.3 & - & 0.1 \\
\hline Hesperidin & 7.0 & 4.1 & - & 3.9 \\
\hline Cinnamic acid & 0.1 & 0.2 & 1.8 & 0.4 \\
\hline Rosmarinic acid & 1.7 & 0.7 & - & 1.3 \\
\hline
\end{tabular}

Antimicrobial activity

Antibacterial activity of essential oils

The results of the antimicrobial screening assays were presented in Table 4 . There were no inhibition zones in the negative controls (methanol). The oils of sage and rosemary exhibited a broad-spectrum inhibitory effect (a strong antibacterial effect against all pathogens). Lavandin oil also showed strong antibacterial effect against majority of pathogens.

Sage, rosemary and hyssop essential oils at 250-1000 $\mu \mathrm{L} \mathrm{mL} \mathrm{m}^{-1}$ concentrations displayed the largest zones of inhibition against $V$. anguillarum compared to other pathogens $(p<0.05)$. Sage and rosemary essential oils at $125 \mu \mathrm{L} \mathrm{mL}^{-1}$ displayed strongest antibacterial effect $(19.5 \mathrm{~mm})$ against $P$. aeuroginosa comparing with other pathogens $(p<0.05)$. However, sage at $500 \mu \mathrm{L} \mathrm{mL}^{-1}$ and rosemary at $1000 \mu \mathrm{L} \mathrm{mL} \mathrm{L}^{-1}$ were also found strong inhibition against $\mathrm{Gr}(+)$ bacteria: S. warneri, V. salmoninarum and L. garvieae. Lavandin at $125 \mu \mathrm{L} \mathrm{mL} \mathrm{L}^{-1}$ showed strongest antibacterial effect against $P$. aeuroginosa and $V$. anguillarum $(\mathrm{p}<005)$. Hyssop oil $\left(250-1000 \mu \mathrm{L} \mathrm{mL}^{-1}\right)$ displayed strongest effect againts $V$. anguillarum (Table 4 see at the last page of this article). A. caviae was the most sensitive to lavandin at $250 \mu \mathrm{L} \mathrm{mL}-1$; A. hydrophila to rosemary $1000 \mu \mathrm{L} \mathrm{mL}-1$; E. tarda to rosemary at $250 \mu \mathrm{L} \mathrm{mL-1;} \mathrm{S.} \mathrm{warneri} \mathrm{to} \mathrm{sage} \mathrm{at} \mathrm{500-1000} \mu \mathrm{L} \mathrm{mL-1;} \mathrm{L.} \mathrm{garvieae} \mathrm{to} \mathrm{sage}$ at $500 \mu \mathrm{L} \mathrm{mL}-1$ and rosemary at $1000 \mu \mathrm{L} \mathrm{mL}-1$ compared to other oils at all concentrations $(p<0.05)$.

\section{Antibacterial activity of extracts}

Rosemary and sage extracts showed strong antibacterial effect against $V$. anguillarum, S. warneri, V. salmoninarum and L. garvieae. However, hyssop and lavandin extracts were found to be ineffective against all tested bacteria (Figure 1) (Table 5). 


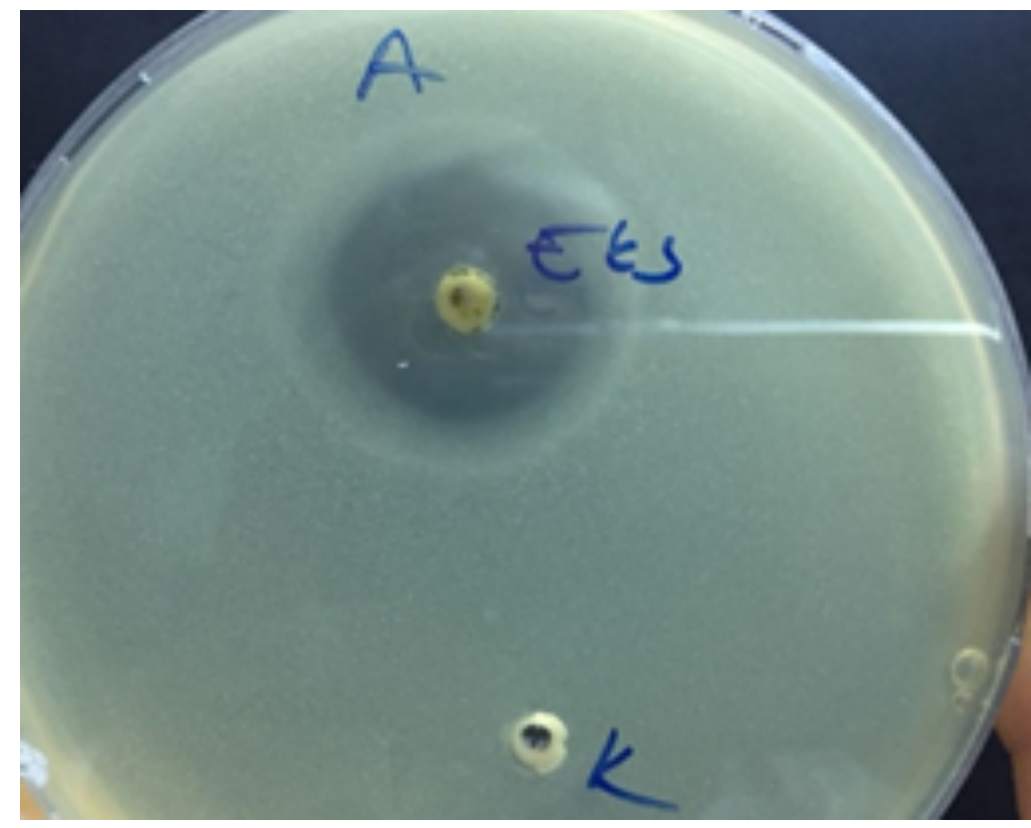

Figure 1 Inhibition zone of sage extract against $V$. anguillarum

\begin{tabular}{ccccc}
\hline \multicolumn{4}{c}{ Table $\mathbf{5}$ Antibacterial activity of rosemary, sage, hyssop and lavandin extracts against } \\
bacterial fish pathogens (inhibition zone diameter, mm) \\
Extracts & Rosemary & Sage & Lavandin & Hyssop \\
\hline A. caviae & - & - & - & - \\
\hline A. hydrophila & - & - & - & - \\
\hline Y. ruckeri & $6.5 \pm 0.70$ & - & - & - \\
\hline E. tarda & $11.5 \pm 0.70$ & - & - & - \\
\hline P. aeuroginosa & - & - & - & - \\
\hline V. anguillarum & $35 \pm 1.41$ & 26 & - & - \\
\hline S. warneri & 26 & $20 \pm 1.41$ & - & - \\
\hline V. salmoninarum & $21.5 \pm 0.70$ & $16 \pm 1.41$ & - & - \\
\hline L. garviae & $21.5 \pm 0.70$ & $18.5 \pm 0.70$ & - & - \\
\hline
\end{tabular}

\section{Discussion}

Essential oils isolated from different aromatic plants are known to have a wide spectrum of antimicrobial activity (Hammer et al., 1999; Baydar et al., 2004). This activity is strongly correlated with the chemical composition of the essential oil and the chemical composition depends on climatic, season, geographic conditions and harvest period. The chemical components of plant species belonging to Lamiaceae family have been studied in literatures. Phenols belong to the largest group of secondary metabolites in plants, foremost of the family Lamiaceae and they exhibit sophisticated biological activity (Carović-StanKo et al., 2016).

R. officinalis essential oil contains mainly compounds including 1,8 cineol, camphor and a-pinene and these compounds have been identified as the most active antimicrobial components in this essential oil (Govaris et al.,2010; Jiang et al.,2011; Sienkiewicz et al.,2013). In the other study were reported that the most important constituents of the 
rosemary were 1,8 -cineole $(78.6 \%)$, alpha-pinene $(5.87 \%)$, tolüene $(12.26 \%)$, camphor $(8.22 \%)$ and berbonone (7.75\%) (Mahmoodi et al.,2012). Bendeddouche et al. (2011), observed that the main constituents of the tested essential oil were camphor $(37.6 \%)$, 1,8 -cineole $(10.0 \%)$, p-cymene-7-ol $(7.8 \%)$ and borneol $(5.4 \%)$. In this study was also determined 1,8 -cineole $(26.36 \%)$, camphor $(29.17 \%)$, borneol $(7.34 \%)$, alpha pinene $(6.72 \%)$ camphene $(4.95 \%)$ in rosemary essential oil.

S. officinalis essential oil is generally characterized by thujones, with a-thujone usually predominating (18-43\%) over $\beta$-thujone (3-8.5\%), camphor $(4.5-24.5 \%), 1,8-$ cineole $(5.5-13 \%)$, a-humulene $(0-12 \%)$, a-pinene $(1-6.5 \%)$, camphene $(1.5-7 \%)$, and bornyl acetate (2.5\% maximum) (Bruneton, 1999). Similarly, in this study was also determined 1,8 -cineole $(27.08 \%)$, thujone $(20.52 \%)$, camphor $(16.99 \%)$, $\beta$-pinene $(4.02 \%)$, linalool $(3.84 \%)$, camphene $(3.67 \%)$, caryophyllene $(3.32 \%)$, a-pinene $(3.06 \%)$, ledene (3.29\%) and borneol (2.67\%). Delemare et al. (2007) also determined a-thujone $(24.8 \%), 1,8$-cineole (14.8\%) and camphor (10.9\%). Santos-Gomes and FernandesFerreira (2001) also reported that a-thujone was the main essential oil compound in the vegetative parts, representing 25.5 and $55.1 \%$ of the essential oils from sage leaves and stems, respectively.

Lavender essential oil composition was usually determined as linalool (25.0-38.0\%), linalyl acetate (25.0-45.0\%), cymene (4.0-10.0\%), terpinen-4-ol (2.0-6.0\%) and camphor (0-0.5\%) (Anonymous, 2002). Baydar and Kineci (2013) noted that the major compounds of lavandin oil were linalyl acetate $(47.7 \%)$, linalool $(34.0 \%)$, camphor $(4.8 \%)$, borneol $(4.2 \%)$, and 1,8-cineole (2.6\%). Similarly, Kara and Baydar (2011) reported linalool (34.3 - 54.6\%), linalyl acetate $(24.0-29.0 \%)$, borneol $(1.6-6.7 \%)$ and camphor $(1.2-6.0 \%)$ in lavandin oil. In the present study also was found linalool (42.21\%), linalyl acetate $(23.61 \%)$ and borneol (5.38\%) in lavandin essential oil.

Kızıl et al. (2010) reported that the major components of Hyssopus officinalis were pinocamphone $(57.27 \%), \beta$-pinene $(7.23 \%)$, terpinene-4-ol $(7.13 \%)$, pinocarvone $(6.49 \%)$, carvacrole $(3.02 \%), \mathrm{p}$-cymene $(2.81 \%)$ and pinocamphone $(2.59 \%)$. Figueredo et al. (2012) noted the main components were pinocarvone (29.17\%), trans-pine camphone (27.19\%), $\beta$-pinene (17.63\%), cispinocamphone (4.68\%) and myrcene $(2.92 \%)$ in hyssop. In the other study was found the main constituents of the oil pinocarvone $(36.3 \%)$, pinocamphone $(19.6 \%), \beta$-pinene $(10.6 \%), 1,8$-cineole $(7.2 \%)$ and isopinocamphone (5.3\%) (Özer et al., 2005). In our study, unlike other studies, betaphellandrene $(49.79 \%)$, linalool $(10.04 \%)$ and elemol- alpha $(3,62 \%)$ in hyssop were determined.

Based on the literatures, the family Lamiaceae seems to be a rich source of plant species containing large amounts of phenolic acids (Lamaison et al.,1991; Li et al.,1993; Kovatcheva et al.,1996; Zgórka and Kawka, 2001). The most prevalent phenolic components in sage extracts are caffeic, vanillic, ferulic, and rosmarinic acids (Pavić et al.,2019). Phenolic acid in rosemary extract was found carnosol, carnosic acid, rosmanol, 7-methyl-epirosmanol, isorosmanol, rosmadial, caffeic acid (Govaris et al.,2010). UsanoAlemany and Panjai (2015) was noted the main phenolic compounds of chlorogenic acid, rosmarinic acid, caffeic acid, ferulic acid in lavandin plant. In $H$. officinalis, the most abundant phenolic acids were considered to be ferulic acid and caffeic acid (Proestos et al.,2005). Similarly, in the present study were determined caffeic acid, p-coum acid, ferulic acid, hesperidine, cinnamic acid and rosmarinic acid as phenolic compounds in the sage, rosemary, lavandin and hyssop extracts.

Plants in Lamiaceae family have a potent antibacterial activity, mostly due to the quantity and quality of phenolic compounds present in them. In this study, rosemary and sage extracts showed strong antibacterial effect against $V$. anguillarum, $S$. warneri, $V$. salmoninarum and $L$. garvieae. The oils of sage and rosemary exhibited a strong antibacterial effect against all fish pathogens. Similary, in the previous study, S. officinalis and $R$. officinalis extracts exhibited a broad-spectrum inhibitory effect both on Gramnegative (Listonella anguillarum serotypes $\mathrm{O} 1$ and $\mathrm{O} 2, \mathrm{Y}$. ruckeri and Photobacterium damselae subsp. piscicida) and Gram-positive bacteria (L. garvieae) (Bulfon et al.,2014). Mahmoodi et al. (2012) also reported extract and essential oil $R$. officinalis showed 
antibacterial effect against L. garvieae. Similarly, in the other study was determined antibacterial activity essential oil of $R$. officinalis against Streptococcus iniae (Roomiani et al.,2013). However, Al Laham and Al Fadel, (2014) reported the antibacterial effect of the extract of $R$. officinalis against $A$. hydrophila. In the other study was also determined antibacterial effect against Aeromonas spp. of $R$. officinalis essential oil (Starliper et al.,2015). In contrast, Ostrand (2012) was reported rosemary oil had a limited effect on fish pathogens, Aeromonas salmonicida and A. hydrophila.

Lavandin (Lavandula $x$ intermedia var. Super) showed strong antibacterial effect against majority of pathogens in the present study. Similarly, Wimalasena et al. (2018) noted lavender (Lavendular angustifolia) essential oil displayed antibacterial activity of against Gram-negative and Gram-positive pathogenic bacteria isolated from cultured olive flounder (Paralichthys olivaceus) in Korea. Hyssop oil (250-1000 $\mu \mathrm{L} \mathrm{mL}^{-1}$ ) displayed strongest effect against $V$. anguillarum in the present study. However, there is no study on antimicrobial activity of $H$. officinalis against fish pathogens.

As a result of this study, 1,8 cineole $(27.08 \%)$, thujone $(20.52 \%)$, camphor $(16.99 \%)$, beta pinene $(4.07 \%)$ in sage; 1,8 cineole $(26.36 \%)$, camphor $(29.17 \%)$, borneol $(7.34 \%)$, alpha pinene $(6.72 \%)$ camphene $(4.95 \%)$ in rosemary; linalool $(42.21 \%)$, linalyl acetate $(23.61 \%)$, borneol $(5.38 \%)$, terpineol $(5.07 \%)$ in lavandin, and beta-phellandrene $(49.79 \%)$, beta-myrcene (\%10.16), linalool (\%10.04) and elemolalpha $(\% 3,62)$ in hyssop were determined. The oils of sage and rosemary a broadspectrum inhibitory effect against Gram (+) and Gram (-) fish pathogens. Lavandin oil also showed strong antibacterial effect against majority of fish pathogens. The spectrum of inhibitory activity of hyssop oil was narrower than other plant oils. In the further studies, diseases resistance against fish pathogens of sage, rosemary and lavandin essential oils should be investigated. Thus, these plant essential oils can be used as an alternative to antibiotics in aquaculture industry.

\section{References}

Abutbul S., Golan-Goldhirsh A., Barazani O., Ofir R. and D. Zilberg, 2005. Screening of desert plants for use against bacterial pathogens in fish. Israeli Journal of Aquaculture - Bamidgeh, 57(2): 71-80.

Al Laham S.A. and F.M. Al Fadel, 2014. Antibacterial activity of various plants extracts against antibiotic-resistant Aeromonas hydrophila. Jundishapur Journal of Microbiology, 7(7): 1-7. DOI: $10.5812 / \mathrm{jjm} .11370$

Anonymous, 2002. Iso 3515:2002 Lavander Oil Quality Standarts.

Bansemir A., Blume M., Schröder S. and U. Lindequist, 2006. Screening of cultivated seaweeds for antibacterial activity against fish pathogenic bacteria. Aquaculture, 252: 7984. DOI: $10.1016 / j$.aquaculture.2005.11.051

Baricevic D. and T. Bartol, 2000: The biological/ pharmacological activity of the Salvia genus. In: Sage The Genus Salvia; Kintzios Se (Eds.). pp. 143-184. Harwood Academic Publishers, Amsterdam.

Baskaya S., Ayanoglu F. and N.P. Bahadırlı, 2016. Biberiye (Rosmarinus officinalis L.) bitkisinin uçucu yağ oranı, uçucu yağ bileşenleri ve antioksidan içeriğinde morfogenetik ve ontogenetik varyabilite. Mustafa Kemal University Journal of Agriculturel Sciences, 21(1):12-20.

Baydar H. 2013: Tıbbi ve aromatik bitkiler bilimi ve teknolojisi (Genişletilmiş 4. Baskı). SDUYayınları, Isparta.

Baydar H., Sagdıc O., Ozkan G. and T. Karadogan, 2004. Antibacterial activity and composition of essential oils from Origanum, Thymbra and Satureja species with commercial importance in Turkey. Food Control, 15(3): 169-172. DOI: 10.1016/S09567135(03)00028-8

Baytop T. 1984: Türkiye'de bitkilerle tedavi. İstanbul Üniversitesi Eczacılık Fakültesi Yayını, İstanbul.

Bendeddouche M.S., Benhassaını H., Hazem Z. and A. Romane, 2011. Essential oil analysis and antibacterial activity of Rosmarinus tournefortii from Algeria. Natural Product Communications, 6: 1511-1514. DOI: 10.1177/1934578X1100601026

Bruneton, J., 1999. Pharmacognosy. 2nd Ed. Intercept Ltd., London, Uk. 1136 Pp.

The Israeli Journal of Aquaculture - Bamidgeh • IJA.73.2021.1305530 
Bulfon C., Volpattı D. and M. Galeottı, 2014. In vitro antibacterial activity of plant ethanolic extracts against fish pathogens. The Journal of the World Aquaculture Society, 45(5): 545-557. DOI: $10.1111 /$ jwas.12151

Carovıć-Stanko K., Petek M., Martına G., Pıntar J., Bedekovıć D., Ćustıć M.H. and Z. Šatović, 2016. Medicinal plants of the family lamiaceaeas functional foods-a review. Czech Journal of Food Sciences,34(5): 377. DOI: 10.17221/504/2015-CJFS

Delamare A.P.L., Moschen-Pıstorello I.T., Artıco L., Attı-Serafını L. and S. Echeverrıgaray,2007. Antibacterial activity of the essential oils of Salvia officinalis L. and Salvia triloba L. cultivated in South Brazil. Food Chemistry, 100(2): 603-608.DOI: 10.1016/j.foodchem.2005.09.078

Diler O., Gormez O., Diler I. and S. Metin, 2017a. Effect of oregano (Origanum onites I.) essential oil on growth, lysozyme and antioxidant activity and resistance against Lactacoccus garvieae in rainbow trout, Oncorhynchus mykiss (Walbaum). Aquaculuret Nutrition, 23: 844-851. DOI: 10.1111/anu.12451

Diler O., Gormez O., Metin S., Ilhan I. and I. Diler, 2017b. Origanum vulgare L. uçucu yağının gökkuşağı alabalığı (Oncorhynchus mykiss)'nda büyüme, lizozim ve antioksidan aktivite ve Vibrio anguillarum'a karşı direnç üzerine etkisi. Acta Aquatica Turcica, 13(1): 42-57. DOI: 10.22392 /egirdir.252029

Dos Santos N.M.S. 2000. Devolopment of immunity in sea bass: a study towards vaccination against pseudotubeculosis. Doctoral Thesis. Univ. Wageningen, Netharlands.

Ekici S., Diler O., Didinen B.I. and A. Kubilay, 2011. Antibacterial activity of essential oils from medicinal plants against bacterial fish pathogens. Journal of the Faculty of Veterinary Medicine, Kafkas University, 17(Supplement A): 47-54.

Fıgueredo G.O., Ozcan M.M., Chalchat J.C., Bagcı Y. and P. Chalard, 2012. Chemical composition of essential oil of Hyssopus officinalis L. and Origanum acutidens. Journal of Essential Oil Bearing Plants, 15(2): 300-306. DOI: 10.1080/0972060X.2012.10644051

Garg S.N., Nagvi A.A., Singh A., Ram G. and S. Kumar, 1999. Composition of essential oil from an annual crop of Hyssopus officinalis grown in Indian plains. Flavour and Fragrance Journal, 14: 170-172. DOI: 10.1002/(SICI)10991026(199905/06)14:3<170::AID-FFJ808>3.0.CO;2-Q

Govarıs A., Botsoglou E., Moulas A. and N. Botsoglou, 2010. Effect of dietary olive leaves and rosemary on microbial growth and lipid oxidation of turkey breast during refrigerated storage. The South African Journal of Animal Science, 40(2):145-155. DOI: $10.4314 /$ sajas.v40i2.57287

Gokce A., Whalon M.E., Cam H., Yanar Y., Demırtas I. and N. Goren, 2007. Contact and tesidual toxicities of thirty plant extracts to colorado potato beetle larvae. Archives Of Phytopathology And Plant Protection, 40: 441-450. DOI: 10.1080/03235400600628013

Hammer K.A., Carson C.F. and T.V. Rıley,1999. Antimicrobial activity of essential oils and other plant extracts. Journal of Applied Microbiology, 86(6): 985-990. DOI: 10.1046/j.1365-2672.1999.00780.x

Haniffa M.A. and K. Kavitha, 2012. Antibacterial Activity of medicinal herbs against the fish pathogen Aeromonas hydrophila. Journal of Agricultural Technology, 8(1): 205-211.

Jankovsky M. and T. Landa, 2002. Genus Hyssopus L.-Recent Knowledge. Horticultural Science, 29: 19-123.

Jıang Y., Wu N., Fu Y.J., Wang W., Luo M., Zhao C.J., Zu Y.G. and X.L. Lıu, 2011. Chemical composition and antimicrobial activity of the essential oil of rosemary. Environmental Toxicology and Pharmacology, 32: 63-68. DOI: 10.1016/j.etap.2011.03.011

Kara N. 2011. Determination of lavender (Lavandula sp.) cultivars suitable for essential oil production and studies on micropropagation possibilities. Doctoral Thesis. Univ. Suleyman Demirel, Isparta, Turkey.

Kara N. and H. Baydar, 2011. Essential oil characteristics of lavandins (Lavandula X İntermedia Emeric Ex Loisel.) of Isparta province, Kuyucak district, where lavender production center of Turkey. Selcuk Journal of Agriculture and Food Sciences, 25 (4): 4145.

Kızıl S., Hasımı N., Tolan V., Kılınc E. and H. Karatas, 2010. Chemical composition, 
antimicrobial and antioxidant activities of hyssop (Hyssopus officinalis L.) essential oil. Notulae Botanicae Horti Agrobotanici Cluj-Napoca, 38(3): 99-103.DOI: $10.15835 /$ nbha3834788

Kovatcheva E., Pavlov A., Koleva I., Ilıeva M. and M. Mıhneva, 1996. Rosmarinic acid from Lavandula vera MM cell culture. Phytochemistry, 43(6): 1243-1244. DOI: $10.1016 /$ S0031-9422(96)00426-8

Lamaıson J.L., Petitjean-Freytet C., Duband F. and A.P. Carnat, 1991. Rosmarinic Acid content and antioxidant activity in french Lamiaceae. Fitoterapia, 62(2): 166-70.

Li J., He L.Y. and W.Z. Song, 1993. Separation and quantitative determination of seven aqueous depsides in Salvia miltiorrhiza by HPTLC scanning. Acta Pharmaceutica Sinica, 28(7): 543-547.

Mahmoodi A., Roomiani L., Soltani M., Akhondzadeh Bastı A., Kamalı A. and S. Taheri, 2012. Chemical composition and antibacterial activity of essential oils and extracts from Rosmarinus officinalis, Zataria multiflora, Anethum graveolens and Eucalyptus globulus. Global Veterinaria, 9(1): 73-79.

Metin S., Didinen B.I., Mercimek E.B. and A.T. Ersoy, 2017. Antibacterial activity of some essential plant oils againts some bacterial fish pathogens. Aquaculture Studies, 17(1): 59-69.

Ostrand S.L., Glenn R.A., Gannam A.L. and K.C. Hanson, 2012. Inhibitory effects of rosemary oil on the in vitro growth of six common finfish pathogens. North American Journal of Aquaculture, 74(2): 230-234. DOI: 10.1080/15222055.2012.675995

Ontas C., Baba E., Ercan M.D., Kaplaner E., Kuçukaydın S. and M. Ozturk, 2016. Antibacterial activity of Citrus limon peel essential oil and Argania spinosa oil against fish pathogenic bacteria. Journal of the Faculty of Veterinary Medicine, Kafkas University, 22(5):741-749. DOI: $10.9775 /$ kvfd.2016.15311

Ozer H., Sahin F., Kılıc H. and M. Gulluce, 2005. Essential oil composition of Hyssopus Officinalis L. Subsp. angustifolius (Bieb.) arcangeli from Turkey. Flavour and Fragrance Journal,20(1): 42-44. DOI: 10.1002/ffj.1421

Pavić V., Jakovljevıć M., Molnar M. and S. Jokıć, 2019. Extraction of carnosic acid and carnosol from sage (Salvia Officinalis L.) leaves by supercritical fluid extraction and their antioxidant and antibacterial activity. Plants, 8(1): 2-14. DOI: 10.3390/plants8010016

Proestos C., Chorianopoulos N., Nychas G.J. and E.M. Komaitis, 2005. RPHPLC analysis of the phenolic compounds of plant extracts. Investigation of their antioxidant capacity and antimicrobial activity. Journal of Agricultural and Food Chemistry, 53: 11901195. DOI: $10.1021 /$ jf040083t

Roomiani L., Soltani M., Akhondzadeh Basti A., Mahmoodi A., Taheri Mırghaed A. and F. Yadollahi, 2013. Evaluation of the chemical composition and in vitro antimicrobial activity of Rosmarinus officinalis, Zataria multiflora, Anethum graveolens and Eucalyptus globulus against Streptococcus iniae; the cause of zoonotic disease in farmed fish. Iranian Journal of Fisheries Sciences, 12(3): 702-716.

Santos-Gomes P.C. and M. Fernandes-Ferreira, 2001. Organ-and season-dependent variation in the essential oil composition of Salvia officinalis L. cultivated at two different sites. The Journal of Agricultural and Food Chemistry, 49(6): 2908-2916. DOI: $10.1021 / \mathrm{jf001102b}$

Sasikumar B. 2004. Rosemary. In: Handbook Of Herbs And Spices; Peter Kv (Eds.). pp: 256-268. Crc Pres, Woodhead Publishing Ltd., England.

Schnick R.A., Alderman D.J., Armstrong R., Le Gouvello R., Ishihara S., Lacierda E.C., Percival S. and M. Roth, 1997. World wide aquaculture drug and vaccine registration progress. European Association of Fish Pathologists Bulletin, 17(6): 251-260. Sienkiewicz M., Lysakowska M., Pastuszka M., Bienıas W. and E. Kowalczyk, 2013. The potential of use basil and rosemary essential oils as effective antibacterial agents. Molecules, 18: 9334-9351. DOI: 10.3390/molecules18089334

Starliper C.E., Ketola H.G., Noyes A.D., Schıll W.B., Henson F.G., Chalupnıckı M.A. and D.E. Dittman, 2015. An investigation of the bactericidal activity of selected essential oils to Aeromonas Spp. Journal of Advanced Research, 6(1): 89-97. DOI: 10.1016/j.jare.2013.12.007 
Turker H. and A.B. Yıldırım, 2015. Screening for antibacterial activity of some turkish plants against fish pathogens: a possible alternative in the treatment of bacterial infections. Biotechnology \& Biotechnological Equipment, 29(2): 281-288. DOI: 10.1080/13102818.2015.1006445

Usano-Alemany J. and L. Panjai, 2015. Effects of increasing doses of UV-B on main phenolic acids content, antioxidant activity and estimated biomass in lavandin (Lavandula $X$ intermedia). Natural Product Communications, 10(7): 1269-1272. DOI: $10.1177 / 1934578 \times 1501000733$

Wimalasena S.H.M.P., Pathirana H.N.K.S., De Sılva B.C.J., Hossain S. and G.J. Heo, 2018. Antimicrobial activity of lavender (Lavendular angustifolia) Oil against fish pathogenic bacteria isolated from cultured olive flounder (Paralichthys olivaceus) in Korea. The Indian Journal of Fisheries, 65(3): 52-56. DOI: 10.21077/ijf.2018.65.3.74436-07

Zgórka G. and S. Kawka, 2001. Application of conventional UV, Photodiode Array (PDA) and Fluorescence $(\mathrm{FI})$ detection to analysis of phenolic acids in plant material and pharmaceutical preparations. Journal of Pharmaceutical and Biomedical Analysis, 24(5-6): 1065-1072. DOI: 10.1016/S0731-7085(00)00541-0 

The Israeli Journal of Aquaculture - Bamidgeh, IJA.72.2020.1305530, 14 pages CCBY-NC-ND-4.0 • https://doi.org/10.46989/001c.21456

Table 4 Antibacterial activity of sage, rosemary, lavandin and hyssop essential oils against different bacterial fish pathogens (inhibition zone diameter, mm $\pm \mathrm{SD})$

\begin{tabular}{|c|c|c|c|c|c|c|c|c|c|c|}
\hline & $\begin{array}{l}\text { Concent } \\
\left.\Lambda \mathrm{L} \mathrm{mL}^{-1}\right)\end{array}$ & $\begin{array}{c}\text { A. } \\
\text { caviae }\end{array}$ & $\begin{array}{c}\text { A. } \\
\text { hydrophila }\end{array}$ & $\begin{array}{c}Y . \\
\text { ruckeri }\end{array}$ & $\begin{array}{l}E . \\
\text { tarda }\end{array}$ & $\begin{array}{c}P . \\
\text { aeuroginosa }\end{array}$ & $\begin{array}{c}\text { V. } \\
\text { anguillarum }\end{array}$ & $\begin{array}{c}\text { S. } \\
\text { warneri }\end{array}$ & $\begin{array}{c}V . \\
\text { salmoninarum }\end{array}$ & $\begin{array}{c}L . \\
\text { garviae }\end{array}$ \\
\hline \multirow{5}{*}{$\begin{array}{l}\stackrel{\Xi}{\mathscr{D}} \\
\text { ज̃ }\end{array}$} & 1000 & $10 \pm 2.82^{\mathrm{ab} . \mathrm{A}}$ & $10^{\text {abc.A }}$ & $14 \pm 8.48^{\text {abc.A }}$ & $9 \pm 1.41^{\text {a.A }}$ & $11.5 \pm 2.12^{\text {ab. } A}$ & $55 \pm 7.07^{\text {f.C }}$ & $28.5 \pm 4.94^{\mathrm{C} . \mathrm{B}}$ & $16.5 \pm 7.77^{\text {cde. } A B}$ & $11.5 \pm 0.7^{\text {c.A }}$ \\
\hline & 500 & $18^{\mathrm{cd} . \mathrm{AB}}$ & $21 \pm 5.65^{\text {cde. }} . \mathrm{BB}$ & $18 \pm 2.82^{\text {d.AB }}$ & $10^{\mathrm{ab} \cdot \mathrm{A}}$ & $21 \pm 4 .{ }^{94 b c . A B}$ & $47 \pm 4.24^{\text {e.C }}$ & $24 \pm 5.65^{c . B}$ & $20 \pm 1.41^{\text {de. } A B}$ & $19 \pm 1.41^{\text {d.AB }}$ \\
\hline & 250 & $17^{\text {bcd.B }}$ & $15.5 \pm 0.7^{\text {abcde. } A B}$ & $15.5 \pm 2.12^{\mathrm{cd} . A B}$ & $12.5 \pm 0.7^{\mathrm{ab} . \mathrm{A}}$ & $18.5 \pm 0.7^{\text {bc. B }}$ & $39.5 \pm 6.36^{\text {e.c }}$ & $12.5 \pm 2.12^{\text {ab. } A}$ & $13 \pm 1.41^{\mathrm{abcd} . \mathrm{A}}$ & $11.5 \pm 2.12^{\mathrm{c} . \mathrm{A}}$ \\
\hline & 125 & $14^{\text {abcd. } A B}$ & $11.5 \pm 2.12^{\text {abcd.A }}$ & $14 \pm 5.65^{\text {abc. } A B}$ & $14 \pm 2.82 \mathrm{ab} . \mathrm{AB}$ & $19.5 \pm 4.94^{\text {abc. B }}$ & - & - & $9 \cdot A$ & $6^{\mathrm{a} . \mathrm{A}}$ \\
\hline & 62.5 & $15 \pm 1.41^{\text {bcd.c }}$ & $12.5 \pm 3.53^{\text {abcde. } B C}$ & $10 \pm 2.82^{\mathrm{ab} . A B}$ & $10^{\mathrm{ab} . \mathrm{AB}}$ & $9.5 \pm 2.12^{\mathrm{a} . \mathrm{AB}}$ & - & - & $8^{. A B}$ & $6^{\mathrm{a} . \mathrm{A}}$ \\
\hline \multirow{5}{*}{ 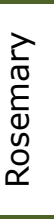 } & 1000 & $12.5 \pm 0.7^{\text {abcd. } A B}$ & $26 \pm 8.48^{e . B}$ & $7^{\mathrm{a} . \mathrm{A}}$ & $8 \pm 1.41^{\mathrm{a} . \mathrm{A}}$ & $14.5 \pm 3.53^{a b c . A B}$ & $60^{f . C}$ & $16 \pm 2.82^{\text {b.AB }}$ & $22 \pm 2.82^{\mathrm{e} . \mathrm{B}}$ & $16 \pm 4.24^{\mathrm{d} . A B}$ \\
\hline & 500 & $13 \pm 2.82$ abcd.$A$ & $19 \pm 1.41$ bcde.A & $11.5 \pm 3.53^{\text {abc.A }}$ & $13 \pm 1.41^{\text {ab.A }}$ & $20.5 \pm 3.53^{\text {abc.A }}$ & $60^{f . B}$ & $15.5 \pm 0.7^{\mathrm{ab} . \mathrm{A}}$ & $20 \pm 8.48^{\text {de.A }}$ & $12 \pm 2.82^{\text {c.A }}$ \\
\hline & 250 & $11.5 \pm 2 .{ }^{12 a b c . A}$ & $22 \pm 2.82^{\text {de.c }}$ & $15.5 \pm 3.53^{\mathrm{cd} . A B}$ & $21 \pm 1.41^{\text {c.C }}$ & $22.5 \pm 9.19^{\text {c.C }}$ & $44.5 \pm 0.7^{e . D}$ & $14.5 \pm 0.7^{\mathrm{ab} . \mathrm{AB}}$ & $14 \pm 2.82^{\text {abcde. } A B}$ & $10 \pm 1.41^{\text {bc.A }}$ \\
\hline & 125 & $12 \pm 1 .{ }^{41 a b c . A}$ & $15 \pm 4.24$ abcde. $A B$ & $9 \pm 2.82^{a b . A}$ & $11.5 \pm 4.94^{\text {ab. }}$ & $21 \pm 4.24^{\text {cd.C }}$ & $11 \pm 1.41^{a . A}$ & $7.5 \pm 0.7^{a b . A}$ & $9 \pm 1.41^{\text {abc. } A}$ & $9 \pm 1.41^{\text {abc.A }}$ \\
\hline & 62.5 & $13 \pm 1.41 \mathrm{abcd} . \mathrm{AB}$ & $24^{C}$ & $7.5 \pm 2.12^{\text {a.A }}$ & $9.5 \pm 3.53^{\mathrm{a} . \mathrm{A}}$ & $21 \pm 9.89^{c d}$ & $11 \pm 1.41^{\mathrm{a} . \mathrm{A}}$ & - & $7^{\mathrm{a} \cdot \mathrm{A}}$ & $6 \cdot A$ \\
\hline \multirow{5}{*}{ 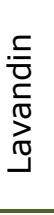 } & 1000 & $14.5 \pm 2 .{ }^{12 \mathrm{abcd} . \mathrm{AB}}$ & $10 \pm 2.82^{\mathrm{abc} . \mathrm{AB}}$ & $7.5 \pm 0.7^{\mathrm{a} . \mathrm{A}}$ & $10.5 \pm 2.12^{\mathrm{a} . \mathrm{AB}}$ & $10.5 \pm 0.7^{\mathrm{ab} . \mathrm{AB}}$ & - & $13.5 \pm 3.53 \mathrm{ab} . \mathrm{AB}$ & $15.5 \pm 4.94^{\text {bcde. } B}$ & $10^{\text {bc. } A B}$ \\
\hline & 500 & $15.5 \pm 6.36 \mathrm{bcd} . \mathrm{AB}$ & $16.5 \pm 2.12^{\mathrm{AB}}$ & $11.5 \pm 0.7^{a b c} . A B$ & $13^{\mathrm{ab} . \mathrm{AB}}$ & $18.5 \pm 2.12^{\text {abc. B }}$ & - & $14 \pm 2.82 \mathrm{ab} . \mathrm{AB}$ & $19 \pm 4.24^{\text {de. } B}$ & $8.5 \pm 0.7^{\text {abc.A }}$ \\
\hline & 250 & $19.5 \pm 7.77^{e}$ & $11 \pm 1.41^{\mathrm{abcd}}$ & $16 \pm 1.41^{\mathrm{cd}}$ & $16^{\mathrm{bc}}$ & $12 \pm 2.82^{a b c}$ & - & $15 \pm 4.24^{\mathrm{ab}}$ & $12 \pm 2.82^{\mathrm{abcd}}$ & $8.5 \pm 0.7^{a b c}$ \\
\hline & 125 & $14.5 \pm 3 .{ }^{53 a b c d . c}$ & $8.5 \pm 2.12^{\mathrm{ab} \cdot \mathrm{A}}$ & $10.5 \pm 0.7^{\mathrm{ab} . \mathrm{AB}}$ & $13 \pm 2.82^{\mathrm{ab} . \mathrm{BC}}$ & $20.5 \pm 0.7^{\mathrm{abc} . \mathrm{D}}$ & $19^{\mathrm{bc} . \mathrm{D}}$ & $9 \pm 1.41^{\mathrm{ab} . \mathrm{AB}}$ & $7^{\mathrm{a} . A}$ & $7^{\mathrm{ab} . \mathrm{A}}$ \\
\hline & 62.5 & $18.5 \pm 0.7^{\text {cd.C }}$ & $4 \pm 2.82 \mathrm{a}^{\mathrm{A}}$ & $10 \pm 1.41^{\text {ab.B }}$ & $9 \pm 2.82^{a \cdot B}$ & $10.5 \pm 0.7^{a b . B}$ & $15^{\mathrm{ab} \cdot \mathrm{c}}$ & - & $7^{\mathrm{a} . \mathrm{AB}}$ & $7 \pm 1.41^{\text {ab. } A B}$ \\
\hline \multirow{5}{*}{ 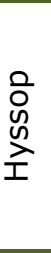 } & 1000 & $14 \pm 1.41^{\text {abcd. } B}$ & $9.5 \pm 0.7^{\mathrm{abc}}$ & $7.5 \pm 0 .{ }^{7 a . A}$ & $9.5 \pm 2.12^{\mathrm{a} . \mathrm{AB}}$ & $12.5 \pm 0 . .^{7 a b c . A B}$ & $26.5 \pm 2.12^{\text {d.c }}$ & $10^{\text {ab.AB }}$ & $7 \pm 1.41^{\text {a.A }}$ & $7^{A}$ \\
\hline & 500 & $\begin{array}{l}14.5 \pm 3.53 \\
\text { abcd.A }\end{array}$ & $13.5 \pm 3.53^{\text {abcde. } A}$ & $9.5 \pm 3.53^{\mathrm{ab} . \mathrm{A}}$ & $10.5 \pm 4.94^{A}$ & $14.5 \pm 0.7^{\mathrm{abc} . \mathrm{A}}$ & $25 \pm 2.82^{\mathrm{cd} . \mathrm{B}}$ & $13 \pm 1.41^{\mathrm{ab} . \mathrm{A}}$ & $10 \pm 4.24^{\mathrm{abc} . \mathrm{A}}$ & $7.5 \pm 0.7 \mathrm{ab} . \mathrm{A}$ \\
\hline & 250 & $15^{\mathrm{bcd} . . \mathrm{B}}$ & $11 \pm 1.41^{\text {abcd. } A B}$ & $10 \pm 1.41 \mathrm{ab} . \mathrm{AB}$ & $13 \pm 1.41^{\text {ab.B }}$ & $10.5 \pm 0.7^{\mathrm{ab} . \mathrm{AB}}$ & $43 \pm 7.07^{\text {e.C }}$ & $7 \pm 1.41^{\text {a.A }}$ & $9.5 \pm 2.12^{\mathrm{abc} . \mathrm{AB}}$ & $6.5 \pm 0 . .^{7 a . A}$ \\
\hline & 125 & $7.5 \pm 2.12^{\mathrm{a}}$ & $19 \pm 5.65^{\text {bcde }}$ & $9 \pm 2.82^{\mathrm{ab}}$ & $12 \pm 4.24^{\mathrm{ab}}$ & $12^{\mathrm{abc}}$ & $15 \pm 4.24^{\mathrm{ab}}$ & - & $8 \pm 1.41^{\mathrm{ab}}$ & - \\
\hline & 62.5 & $12 \pm 1.41^{\text {abc. BC }}$ & $8.5 \pm 2.12^{\mathrm{ab} . \mathrm{AB}}$ & $6.5 \pm 2.12^{\mathrm{a} . \mathrm{A}}$ & $9 \pm 1.41^{\text {a.AB }}$ & $9.5 \pm 0.7^{a . A B}$ & $14^{\mathrm{ab} \cdot \mathrm{c}}$ & - & $8 \pm 2.82^{\text {ab.AB }}$ & - \\
\hline
\end{tabular}

* Corresponding author: Tel.: +90 2462146436, e-mail: behiredidinen@hotmail.com 